\title{
NOTES ON THE BIOLOGY OF SOME POGONOPHORA
}

\author{
By A. J. SouthWARd and E. C. Southward \\ The Plymouth Laboratory
}

(Text-fig. I)

\begin{abstract}
A great deal is now known of the anatomy and histology of the pogonophores, mainly through the researches of Ivanov (for references see Ivanov, I963). Much less is known about their reproduction, the embryology having been described only from chance findings in preserved material (Ivanov, I957; Jägersten, 1957), while the deductions that have been made as to the possible mode of feeding and general behaviour are largely speculative (Ivanov, I952, I955; Jägersten, I956; Kirkegaard, I96I). As long as the animals were regarded as very deep sea forms little advance in their biology could be expected. When, however, some species began to be found in collections made in shallower water (Jägersten, I956; Kirkegaard, I958; Southward, I958) hopes were raised that studies on live material would elucidate many puzzling features of these animals-e.g. the mode of digestion in the absence of a gut-and help in determining their relationship to the other groups belonging to the echinoderm-chordate stem (Deuterostomia). Unfortunately practically all species recorded from the continental shelf come from rather inaccessible places and are very small, hence little information has so far been published.
\end{abstract}

The group was first recorded from the Atlantic as recently as I958 (Southward, A. J. \& E. C., I958; Southward, E. C. \& A. J., I958; Southward, E. C., I959) and work from Plymouth has been mainly exploratory. Dredging has been carried out on seven cruises of R.V. 'Sarsia' in the period I958-62, in areas ranging from the west coast of Ireland and the southern Bay of Biscay to the entrance of the Bristol Channel. One of us (A.J.S.) was able to make some further dredge hauls on a line from Plymouth to Madeira during a cruise of R.R.S. 'Discovery II', while the other (E.C.S.) has worked I4 stations in the deeper parts of the Clyde Sea and Loch Fyne from R.V. 'Calanus'.

Pogonophores were taken on most of the 'Sarsia' cruises, the best finds being along the continental slope in 1000 to $1500 \mathrm{~m}$., with particularly rich populations of large species in the complex submarine valleys around $48^{\circ} 30^{\prime} \mathrm{N}$., $10^{\circ} \mathrm{IO}^{\prime} \mathrm{W}$. None were taken in the Clyde area, off the entrance to the Bristol Channel or on the abyssal plain of the eastern Atlantic, and none have yet been found in samples we have examined from the Irish Sea and off the 
south coast of Ireland. Some small species were, however, found in 732$774 \mathrm{~m}$. close inshore off Madeira, and the occurrence of another species off Dingle Bay, Ireland, in the vicinity of $5 \mathrm{I}^{\circ} 54^{\prime} \mathrm{N}$., $\mathrm{II}^{\circ} \mathrm{00} \mathrm{o}^{\prime} \mathrm{W}$., at $\mathrm{I} 45^{-\mathrm{I}} 65 \mathrm{~m}$. confirmed. The same, or a related form has recently been found in the North Minch, off the Butt of Lewis (McIntyre, 1963) and these two finds constitute the only records of the occurrence of Pogonophora on the continental shelf of the British Isles.

It is hoped to present full details of distribution, occurrence and associated faunas in a later contribution. Here we describe some interesting features of the biology of these enigmatic animals, observed on live material.

We are indebted to Lt.Cdr. C. A. Hoodless and the crew of R.V. 'Sarsia' for their unfailing help and interest in this work. Thanks are due to the Director of the National Institute of Oceanography for permission to take part in a cruise of R.R.S. 'Discovery II' and to the Director of the Scottish Marine Biological Association's Millport Laboratory for placing R.V. 'Calanus' at our disposal.

\section{BLOOD AND PIGMENTS}

As Ivanov $(\mathrm{I} 960 a, b)$ has noted, the blood of all pogonophores so far examined alive is coloured red. Our observations indicate that this pigment is held in solution and is a haemoglobin. It remains red when reduced with sodium hydrosulphite and gives a positive benzidine reaction. Absorption spectra obtained on board ship with a Zeiss eyepiece spectrometer focussed on oxygenated blood in the blood-vessels agree with those of other haemoglobins reviewed by Eliassen (I954) and Fox (1949). Two well marked absorption bands were observed in Siboglinum atlanticum, $S$. inerme, and two other species of the genus, all with maxima at approximately 545 and $585 \mathrm{~m} \mu$. In Oligobrachia ivanovi the bands were weaker, perhaps due to interference from yellow and brown epidermal pigments, and had maxima at approximately 547 and $575 \mathrm{~m} \mu$.

The epidermal pigments of $O$. ivanovi are probably not breakdown products of haemoglobin, though insufficient could be obtained for full tests. The brown pigment occurs as groups of granules which dissolve easily in acidified methanol when fresh. An absorption curve was obtained for us by Mr F. A. J. Armstrong with the Beckman recording spectrophotometer, and showed general absorption in the blue and blue-green with weakly defined maxima at $397,460,505$ and possibly $540 \mathrm{~m} \mu$, suggesting the presence of ommochromes and/or echinochromes.

The remaining species in our collections, belonging to the genera Siboglinum and Diplobrachia, have no pigment other than that in the blood and tube. 


\section{TUBES}

Pogonophores appear to spend much time inside their tubes, and in several species the anterior end of the tube is often found closed (see for example Fig. IA). The tubes of species so far tested are composed of chitin and protein (Brunet \& Carlisle, 1958; Ivanov, 1963). Those of $O$. ivanovi are very stiff and dark brown, appearing black by reflected light. The species of Siboglinum have light-coloured flexible tubes, varying from light grey to orange-brown. Both types of tube have been tested for permeability, using freshly collected uninhabited lengths. These lengths were probably cut off by the sharp edge of the dredge while the animal remained further down in the deposit.

Preliminary experiments were made at sea. Lengths of tube containing sea water were placed in small vessels containing a strong solution of sodium chloride, leaving both ends of the tube in the air. The level of water inside the tube fell within a few minutes, indicating that water was passing freely through the wall. The same result was obtained with a strong solution of sucrose, and in each case the difference in level was maintained for more than ro minutes. The outsides of the tubes were then rinsed off with distilled water and the experiment repeated with distilled water outside the tube. The level within rose rapidly and the ends of the tube began to overflow. These results indicated that the walls of the tube are freely permeable to water but less so to electrolytes and small molecules.

Similar experiments were later made in the laboratory using $S$. atlanticum tubes. One tube had both ends open as before, the other had one end sealed (as often found in nature; Southward \& Southward, 1958) and the other open to the air. These were filled with sea water and the level measured in each open end. They were then suspended in an empty vessel, which was filled with 10\% sucrose solution (ca. 6 atm. o.P.) to the level of the water in the tubes. The water level in each dropped rapidly and reached a minimum after $40 \mathrm{~min}$, when the water in the tube had decreased to less than $50 \%$ of the original volume. After $\mathrm{I} \frac{1}{2} \mathrm{~h}$ the level inside the tube began to rise again; after $24 \mathrm{~h}$ there was still a slight difference in level in the tube open at both ends, while the closed tube appeared to have reached equilibrium. A similar pair of tubes, filled with sea water, were carefully rinsed off with distilled water and then placed in vessels of distilled water with the open ends bent over so that they were outside and below the top of the vessel. Within a few minutes the small spaces at the ends filled up and the tubes began to overflow a little. At this stage a sample of water from the vessels gave no precipitate with silver nitrate. A slight precipitate was perceptible after $\mathrm{I} \frac{1}{2} \mathrm{~h}$, in the experiment with the tube closed at one end, and a definite precipitate after $2 \mathrm{~h}$. The water containing the tube open at both ends gave only a slight reaction after $2 \frac{1}{4} \mathrm{~h}$ and a definite precipitate was not seen until nearly $3 \mathrm{~h}$ had passed. The sealed end of the tube is the thin-walled anterior end and, as might be expected, it seems to allow a slightly quicker penetration by solutes than the other lengths of tube used.

These experiments show that the tube of $S$. atlanticum acts as an imperfect semi-permeable membrane, being freely permeable to water but much less so to ions and small molecules, which eventually pass through. Large molecules were not tested but it has been noticed that blood liberated inside the tube by damaged animals remained there for several days. From these 
results we conlude that dissolved gases may pass in and out through the tube wall while the animal remains inside, but that it is less likely that sufficient dissolved organic matter for nutrition can enter through the wall from the water or the mud.

\section{REPRODUCTION}

Batches of up to roo embryos were found in several tubes of Oligobrachia ivanovi, sealed off from the outer world in the anterior end (Fig. IA). All in each tube were in the same stage of development, as appears to be usual in the group (Ivanov, I957). Some remained alive for four weeks in the cold room at $5^{\circ}-7^{\circ} \mathrm{C}$, but little further development occurred.

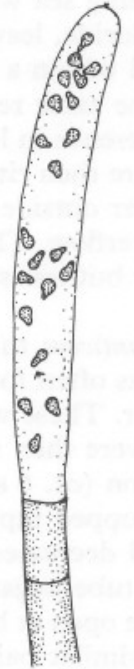

A

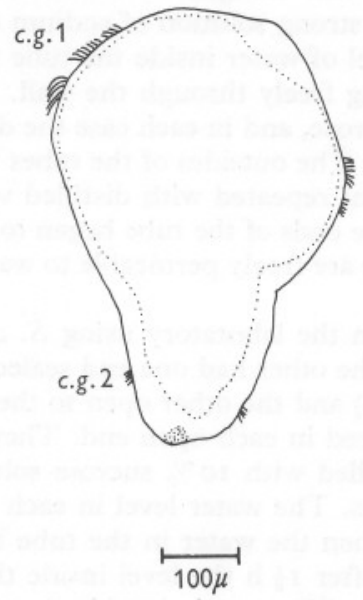

B

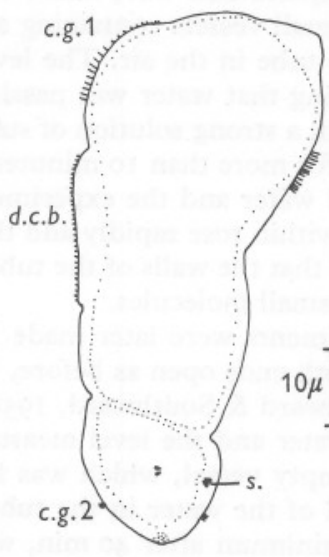

C

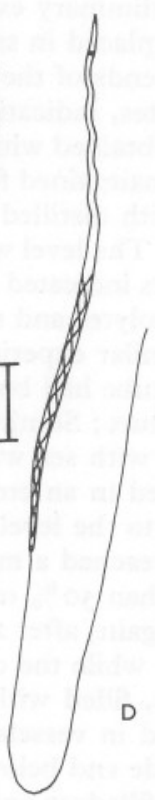

Fig. I. A, B. C. Oligobrachia ivanovi. A, sketch of living embryos inside transparent end of parental tube; B, pear-shaped embryo (optical median section); c, older elongated embryo, showing two of the four pairs of setae; dotted lines show the approximate extent of yolky material in the living embryo. c.g. I, anterior ciliated girdle; c.g. 2, posterior ciliated girdle; d.c.b., dorsal ciliated band; s., setae. D, Siboglinum atlanticum: spermatozoon; the spiral threads and black spots appear bright by Reichert Anoptral contrast; the position of the nucleus has not been determined.

Two distinct stages were recognized: a spherical stage; and a pear-shaped stage, which was apparently capable of extending to a more worm-like stage though retaining a swollen anterior end (Fig. I B, C). All stages bore two girdles of cilia and rotated slowly on their axes in a clockwise direction when seen from the anterior end. Within the tube the embryos moved round aim- 
lessly in circles, and when removed to a dish the circling continued on the bottom of the dish, in a clockwise direction viewed from above. No reaction was noted to a light gradient under tungsten illumination. In addition to the two girdles of cilia, most of the pear-shaped or elongate embryos had a lengthwise ciliated band on the second segment (cf. Siboglinum-Jägersten, 1957). The first setae seem to develop a little later than the ciliated band and were found in some of the elongated embryos of Oligobrachia (Fig. IC) and also in a worm-like stage of Siboglinum inerme. The earlier stages of the latter species have not been seen, though found in another species of Siboglinum from off Dingle Bay.

Some mature males of Siboglinum atlanticum were obtained on the most recent cruise. After softening the spermatophores overnight in sea-water, the spermatozoa could be separated easily (Fig. ID). In other invertebrates a filiform 'head' end of the spermatozoon is associated with modified methods of fertilization in which the individual sperms are not liberated into the external medium (Franzén, I956). It is characteristic of pogonophores that the sperms are enclosed in spermatophores, each provided with a long filament. Although Ivanov (1963) has suggested that the spermatophores are liberated into the water, there is a possibility that some form of copulation occurs, at least among the smaller species which can occasionally exist in very dense associations (up to 200 per $\mathrm{m}^{2}$ off California according to Hartman, I96I ; up to 50 per $\mathrm{m}^{2}$ off Ireland according to quantitative data supplied by $\mathrm{Mr}$ N. A. Holme). The larger forms, however, may be too thin on the ground for transfer of gametes direct, unless, of course, they are gregarious. Our best haul of Oligobrachia ivanovi provided 25 anterior ends of tubes from approximately $0.3 \mathrm{~m}^{3}$ of mud brought up by the dredge. If the dredge is assumed to have penetrated to at least $10 \mathrm{~cm}$ deep in the mud, as suggested by a maximum tube-length, incomplete, of $13 \mathrm{~cm}$, then the density was of the order of 8 per $\mathrm{m}^{2}$. This indicates an average spacing of $35 \mathrm{~cm}$ between individuals, considerably more than the total length of the largest animal found.

\section{GENERAL BEHAVIOUR}

Living specimens of several species of pogonophores have been observed on three cruises, and have survived in the cold room at the laboratory for up to 2 weeks, but very little activity has been seen. To some extent this may be due to damage, since most specimens, if not all, lack part of the posterior end of the body, and have already lost some blood when examined. It seems probable from the anatomy that their movements, particularly of the tentacle, are partly hydrostatic, and brought about by a flow of blood and body fluids from one part of the animal to another (cf. Parry \& Brown, 1959; Morton, 1959; Crisp \& Southward, I96I); what we see is perhaps a feeble remnant of possible activity. No sudden reaction to touch has been noted, though the 
animals seem to cling tenaciously to their tubes. If the front part of the tube is dissected off from the body the mesosoma contracts dorsally and the tentacle or tentacles coil up, but no further change takes place. Some slow movement up and down can be seen inside the tube, and undoubtedly the adhesive plates and girdles act as anchorages, but again no sudden movements have been seen.

There does not appear to be any regular circulation of water within the tube of Siboglinum, though a tract of short cilia on the dorsal side of the metasoma move particles that are actually touching them.

The absence of any real activity, whether due to damage, temperature, illumination or other unfavourable environmental factors has made it impossible to design feeding experiments. Speculation by Ivanov (I955), Jägersten (1956, 1957) and Kirkegaard (196I) has produced three suggested mechanisms of feeding and digestion in the single tentacle forms: $(a)$ the coiled tentacle and pinnules form a ciliated funnel for filter-feeding, digestion taking place in the funnel either outside or inside the tube, and the products absorbed by the tentacle; $(b)$ the tentacle explores the surrounding substrate and picks up, by secretion or coiling, particles or animals, which are then digested inside the coiled up tentacle either outside or inside the tube; (c) organic matter in solution is absorbed by the tentacle, the process being assisted by ciliary currents. Of these alternatives $(a)$ is unlikely generally since some species are without cilia or even pinnules on the tentacle, while $(c)$ is a much discussed hypothesis that seems impossible to prove or disprove (see Corner, 196I, for a recent discussion); the remaining suggestion seems inherently more probable, and an analogous feeding mechanism, but not digestion, is practised by Dentalium entalis (Morton, I959). From the ability of the animal to seal off the end of its tube, and the relatively semi-permeable nature of the walls, it seems possible that captured food particles might be drawn inside the tube by the tentacle and there digested by enzymes produced by some of the numerous glands on other parts of the body, the product being absorbed directly. The cuticle that covers most of the epidermis (Ivanov, I963) does not seem to have much structural function in a tubicolous animal, and may well be part of a mechanism to prevent auto-digestion.

\section{CONCLUSION}

It is obvious how little is known about the biology of the pogonophores, and how much work is needed. It seems to us that the most useful approach now is to pursue the larger species that are found in very shallow water in the Arctic Ocean (Southward, I962; Ivanov, 1962). Little further can be expected to be learned from deep-water forms, wrenched out as they are from the bottom with a sharp-edged dredge, and then subjected to several hours suffocation in mud, changes of pressure, light and temperature before being 
examined. Searches must continue, to attempt to bridge the gap in the lifehistory that exists at the moment between the partly tentacled, gutless, late embryo in its parent's tube, and the fully grown adult, also without gut, in its own long tube.

\section{SUMMARY}

Observations have been made on living pogonophores obtained from the continental slope to the south-west of the British Isles and from the continental shelf off the west coast of Ireland.

The blood of five species examined contains haemoglobin in solution. The tube appears to be freely permeable to water, but less so to electrolytes and small molecules.

The appearance and behaviour of living embryos is noted and the spermatozoon of one species figured. Possible feeding and other behaviour is discussed and it is concluded that the best line of future investigation lies with the shallow-water forms found in the Arctic Ocean.

\section{REFERENCES}

Brunet, P. C. J. \& CARLisle, D. B., 1958. Chitin in Pogonophora. Nature, Lond., Vol. I82, p. I689.

CORNER, E. D. S., I96r. On the nutrition and metabolism of zooplankton. I. Preliminary observations on the feeding of the marine copepod Calanus helgolandicus (Claus). F. mar. biol. Ass. U.K., Vol. 4I, pp. 5-16.

CRISP, D. J. \& SouthWARD, A. J., I96I. Different types of cirral activity of barnacles. Phil. Trans. B, Vol. 243, pp. 271-308.

ELIASSEN, E., I954. The physiology of the vascular system of invertebrates. I. A monograph on the blood pigments. Univ. Bergen Arb. naturv. R., I953, Nr. II.

Fox, H. M., 1949. On chlorocruorin and haemoglobin. Proc. roy. Soc. B, Vol. 136, pp. $378-88$.

FRANZEN, A., 1956. On spermiogenesis, morphology of the spermatozoon, and biology of fertilization among invertebrates. Zool. Bidr. Uppsala, Bd. 3I, pp. 355-482.

Hartman, O., 1961. New Pogonophora from the eastern Pacific Ocean. Pacific Sci., Vol. I5, pp. 542-6.

Ivanov, A. V., I952. New Pogonophora from the far eastern seas. Zool. Zh., Vol. 31, pp. 372-91. (In Russian, partly translated in: Syst. Zool., Vol. 3, pp. 69-79.) 1955. External digestion in Pogonophora. C.R. Acad. Sci. U.R.S.S., T. I00, pp. 38I-3. (In Russian, translated in: Syst. Zool., Vol. 4, pp. I74-6.)

1957. Materials on the embryonic development of Pogonophora. Zool. Zh., Vol. 36, pp. I1 27-44. (English summary.)

I960a. Pogonophores. Fauna Rossii, No. 75, 271 pp. (In Russian.)

- 1960 b. Embranchement des pogonophores. In: Grassé, P. (ed.), Traité de Zoologie, T. 5, fasc. 2, pp. 152I-1622.

1963. Pogonophora. New York and London: Academic Press.

JÄGERSTEN, G., 1956. Investigations on Siboglinum ekmani, n.sp., encountered in Skagerak. With some general remarks on the group Pogonophora. Zool. Bidr. Uppsala Bd. 31, pp. 2 I I-48.

- 1957. On the larva of Siboglinum. Zool. Bidr. Uppsala, Bd. 32, pp. 67-80. 
KIRKEgAaRD, J. B., I958. Records of the group Pogonophora in the Skagerak. Nature, Lond., Vol. I81, pp. I086-7.

- 196r. Polychaeta and Pogonophora from the deepest part of the Skagerak. Vidensk. Medd. dansk naturh. Foren. Kbh., Bd. I23, pp. 2 I I-26.

McIntyre, A. D., 1963. Pogonophora from British coastal waters. Nature, Lond., (in the Press).

Morton, J. E., 1959. The habits and feeding organs of Dentalium entalis. F. mar. biol. Ass. U.K., Vol. 38, pp. 225-38.

ParRy, D. A. \& Brown, R. H. J., I959. The hydraulic mechanism of the spider leg. F. exp. Biol., Vol. 36, pp. 423-33.

Southward, A. J., 1958. Abundance of Pogonophora. Nature, Lond., Vol. I82, p. 272.

Southward, A. J. \& E. C., 1958. Pogonophora from the Atlantic. Nature, Lond., Vol. I8r, p. 1607.

Southward, E. C., 1959. Two new species of Pogonophora from the north-east Atlantic. F. mar. biol. Ass. U.K. Vol. 38, pp. 439-44.

- 1962. A new species of Galathealinum (Pogonophora) from the Canadian Arctic. Canad. F. Zool., Vol. 40, pp. 386-9.

SouthWARD, E. C. \& A. J., I958. On some Pogonophora from the north-east Atlantic, including two new species. F. mar. biol. Ass. U.K., Vol. 37, pp. 627-32. 